ARAŞTIRMA / RESEARCH

\title{
Effect of the metabolic syndrome on the quality of life and sleep in women
}

Kadınlarda metabolik sendromun uyku ve yaşam kalitesi üzerine etkisi

\author{
Rabiye Çırpan1D, Arife Zuhal Değirmencioğlu2 (D), Semra Kocaöz
}

${ }^{1}$ Niğde Ömer Halisdemir University, Niğde Zübeyde Hanım School of Health, Nursing Department, Department of Internal Medicine Nursing, ${ }^{3}$ Department of Obstetrics and Gynecology Nursing, Niğde, Turkey

${ }^{2}$ Niğde Ömer Halisdemir University, Medical Faculty, Medical Sciences Department, Department of Internal Medicine, Niğde, Turkey

\begin{abstract}
Purpose: This study was conducted to determine the metabolic syndrome prevalence in women and evaluate its effect on the quality of life and sleep.

Materials and Methods: This descriptive and crosssectional study was completed with 372 women. Data were collected using a descriptive questionnaire, the Pittsburgh Sleep Quality Index, and the SF 36 Quality of Life Scale.. Results: The metabolic syndrome prevalence in women was $41.9 \%$, according to the International Diabetes Federation diagnostic criteria. The mean scores obtained from the sleep quality index by those with metabolic syndrome were significantly higher than those without metabolic syndrome. The median scores obtained from the physical function and role difficulty, pain, general health perception, and mental summary sub-dimensions of the SF-36 quality of life scale by the women who were found to have metabolic syndrome were lower than those without metabolic syndrome.

Conclusion: Metabolic syndrome was found to be common in women and to affect the quality of life and sleep negatively in women in this study. We, therefore, recommend women to be evaluated in terms of metabolic syndrome at regular intervals and healthcare professionals to provide training and consultancy services to promote healthy living behaviors that could improve their quality of life and sleep.
\end{abstract}

Cukurova Medical Journal 2021;46(3):1108-1116.

Keywords: Metabolic syndrome, sleep, quality of life, women
Öz

Amaç: Çalışma, kadınlarda metabolik sendrom prevalansını belirlemek ve metabolik sendromun uyku ve yaşam kalitesi üzerindeki etkisini değerlendirmek amacıyla yapılmıştır.

Gereç ve Yöntem: $\mathrm{Bu}$ tanımlayıcı ve kesitsel tipteki çalışma 372 kadınla tamamlanmıştır. Araştırmanın verileri tanımlayıcı anket formu, Pittsburgh Sleep Quality Index (PSQI) ve SF 36 Yaşam Kalitesi Ölçeği kullanılarak toplanmıştır..

Bulgular: Çalışmamızda Uluslararası Diyabet Federasyonu tanı kriterlerine göre kadınların \%41.9'unda metabolik sendrom olduğu tespit edilmiştir. Kadınların uyku kalitesi değerlendirildiğinde, metabolik sendrom saptanan kadınların Pittsburgh Sleep Quality Index toplam puan ortalamasinın, metabolik sendrom saptanmayan kadınlardan daha yüksek olduğu belirlenmiştir. Metabolik sendrom saptanan kadınların SF-36 yaşam kalitesi ölçeğinin fiziksel fonksiyon, fiziksel rol güçlügü, ağrı, genel sağlık alg1sı alt boyut puan ortancaları ile mental özet skoru alt boyut puan ortancasinın metabolik sendrom saptanmayan kadınlardan daha düşük olduğu belirlenmiştir.

Sonuç: Çalışma sonucunda metabolik sendromun kadınlarda yaygın olarak görüldüğü, kadınların uyku ve yaşam kalitesini olumsuz yönde etkilediği tespit edilmiştir. $\mathrm{Bu}$ sonuçlar doğrultusunda kadınların uyku ve yaşam kalitelerini iyileştirebilmek için düzenli aralıklarla metabolik sendrom yönünden değerlendirilmesi ve kadınlara sağlıklı yaşam davranışları kazanmaları konusunda eğitim ve danısmanlık hizmetlerinin verilmesi önerilmektedir.

Anahtar kelimeler: Metabolik sendrom, uyku, yaşam kalitesi, kadın

Yazışma Adresi/Address for Correspondence: Dr. Rabiye Çırpan, Niğde Ömer Halisdemir University, Niğde Zübeyde Hanım School of Health, Department of Internal Medicine Nursing, Niğde, Turkey E-mail: rabiyecirpan@gmail.com Geliş tarihi/Received: 07.04.2021 Kabul tarihi/Accepted: 14.07.2021 Çevrimiçi yayın/Published online: 23.07.2021 


\section{INTRODUCTION}

The metabolic syndrome (MetS) prevalence has increased globally due to physical inactivity, highcalorie intake, and increased obesity. It is an important health problem with high morbidity and mortality. MetS occurs due to genetic and environmental factors, and it is a set of cardiometabolic risk factors characterized by high blood pressure, high blood glucose and triglyceride (TG), abdominal obesity, and low high-density lipoprotein cholesterol (HDL-C) ${ }^{1-3}$. MetS is reported to increase the risk of developing type 2 diabetes mellitus (DM) 5 times and developing arteriosclerotic cardiovascular disease 2 to 3 times ${ }^{4,5}$.

MetS is identified according to different diagnostic criteria by various organizations and study groups. The National Cholesterol Education Program Adult Treatment Panel III (NCEP ATP III) and the International Diabetes Federation (IDF) identification criteria are most commonly used ${ }^{5,6}$. The MetS prevalence varies based on the criteria used in its identification, race, ethnic origin, age, and gender ${ }^{3}$. It is reported to vary between $10 \%$ and $40 \%$ worldwide $^{1}$. MetS prevalence in adults aged 20 and over was $33.9 \%$ divided as $28.0 \%$ in males and $39.6 \%$ in females in a study conducted using the NCEP ATP III criteria in our country ${ }^{2}$. The MetS prevalence was found to be $36.7 \%$ according to the NCEP ATP III criteria and $43.9 \%$ according to the IDF criteria in the Prospective Urban Epidemiological (PURE) Study PURE Turkey. The prevalence of MetS in women was found to be higher than in men in the same study ${ }^{7}$.

Many risk factors play a role in the development of $\mathrm{MetS}^{5,6}$. One of these health problems that affect the development of MetS and that can also be seen following its development is sleep disturbance ${ }^{8-10}$. Sleep is a basic human need and is an important factor affecting the individual's well-being and quality of life. Individuals need adequate and quality sleep to develop and repair tissues, protect energy and physical and mental functions, regulate metabolic and hormonal processes, and maintain health ${ }^{11,12}$. A decrease in sleep duration or poor sleep quality causes an increase in sympathetic nervous system activity and changes in insulin secretion, cortisol, and growth hormone, and leptin and ghrelin, which are the hormones regulating the sensation of appetite and satiety. These changes lead to deterioration in glucose metabolism, blood pressure, and appetite regulation, increasing the risk of obesity, insulin resistance, hypertension, diabetes, and MetS development ${ }^{13,14}$. The sleep duration (short or long) (5,16 and sleep quality ${ }^{8-10,14,16}$ have been related to MetS. In addition to sleep quality, MetS itself and the chronic diseases that may develop due to MetS can decrease the quality of life by affecting the physical, mental and social functions of the individual ${ }^{17,18}$. MetS has been reported to affect the quality of life negatively ${ }^{18-21}$.

Studies are evaluating the effect of MetS on the quality of life $\mathrm{e}^{18,20,21}$ and sleep $9,10,14$ separately in the literature. However, we did not come across a study evaluating the effect of MetS on the quality of life and sleep in women together. Therefore, this study was conducted to determine the prevalence of MetS in women and evaluate its effect on the quality of life and sleep. The results obtained from this study could contribute to determining the effect of MetS on sleep and the quality of life in women, increasing the awareness of health care professionals on the subject and planning treatment and care services directed at solving the problem. We also believe that the findings of our study could contribute to the literature information as there is only limited research data on the investigated subject.

In this study, answers to questions "What is the prevalence of MetS in women?", "Does MetS have an effect on sleep quality in women?", "Does MetS have an effect on quality of life in women?" were sought.

\section{MATERIALS AND METHODS}

\section{Sample}

This research is a descriptive and cross-sectional study. The study population consisted of women who had presented for a physical examination to the internal medicine outpatient departments of a training and research hospital between 12 February and 6 April 2018. The sample of the study was identified by using the sample size formula with an unknown population. Using a $95 \%$ confidence interval, a p-value of $0.385^{22}$, and the sample size formula with an unknown population, the number of women required to be included in the sample was calculated as 364, and the study was completed with 372 women who met the study inclusion criteria.

Study inclusion criteria were all women (1) being over the age of 18; (2) being able to understand and answer the questions; and (3) having agreed to participate in the study. The exclusion criterion of the study was 
the presence of a physical or mental disability in the subject.

Before starting the study, approval was obtained from the Niğde Ömer Halisdemir University Ethics Committee (Date: 29.12.2017, approval number: 2017/13-01) and written institutional approval from the Niğde Province Health Directorate and the training and research hospital where the study was conducted. The women included in the study were informed of the purpose of the study, and verbal and written informed consent was taken.

\section{Measures}

The data in the study were collected by using a descriptive questionnaire created by the investigators by reviewing the literature $2,7,9,10,14,20,21$, the Pittsburgh Sleep Quality Index (PSQI)and the SF-36 Quality of Life Scale.

\section{The descriptive questionnaire}

The descriptive questionnaire included 25 questions evaluating the socio-demographic and disease- and health-related characteristics of the women. Systolic and diastolic blood pressure and height, weight, the women's waist circumference were also taken, and the body mass index (BMI) was calculated. The fasting plasma glucose (FPG), HDL-C, and TG values of the women were recorded from the routine laboratory test results obtained after at least 8 hours of fasting.

The IDF diagnosis criteria were used to identify MetS in our study. The diagnosis of MetS was based on the presence of at least 2 of the criteria defined below, provided that IDF Central obesity was present. Central obesity was determined using the waist circumference specific to the ethnic group. MetS criteria were (1) Waist circumference $(\geq 94 \mathrm{~cm}$ for Europid male and $\geq 80 \mathrm{~cm}$ for Europid female); (2) Raised TG $(\geq 150 \mathrm{mg} / \mathrm{dL}$ or receiving specific treatment for this lipid abnormality); (3) Reduced HDL-C $(<40 \mathrm{mg} / \mathrm{dL}$ in males, $<50 \mathrm{mg} / \mathrm{dL}$ in females or receiving specific treatment for this lipid abnormality); (4) Raised blood pressure (systolic BP $\geq 130$ or diastolic $\mathrm{BP} \geq 85 \mathrm{mmHg}$ or treatment of previously diagnosed hypertension); and (5) Raised FPG (FPG $\geq 100 \mathrm{mg} / \mathrm{dL}$ or previously diagnosed type 2 diabetes) $)^{23}$.

\section{Pittsburgh Sleep Quality Index (PSQI)}

PSQI was developed by Buysse et al. in 198924. Turkish adaptation of the PSQI was conducted by
Ağargün et al. ${ }^{25}$. The index contains 24 questions, including 19 self-evaluation questions and five answered by the spouse or roommate of the individual. The 18 items included in the scoring are grouped as seven components. Each item is evaluated over 0-3 points. The sum of the scores of 7 components gives the total PSQI score. The total score is between 0 and 21. The Cronbach's alpha value of the index is 0.80 in the study conducted by Ağargün et al. ${ }^{25}$. The Cronbach's alpha value of PSQI was found to be 0.74 in our study.

\section{SF-36 Quality of Life Scale (SF-36 QoLS)}

This scale is an individual evaluation scale used commonly in health-related quality of life studies. The scale contains 36 items and consists of the eight sub-dimensions of physical function, social function, physical role difficulty, emotional role limitations, mental health, energy/vitality, bodily pain, and general health perception ${ }^{26}$. Summary scores can also be obtained for the physical and mental components of the health sub-dimensions of the scale. Total scores are obtained separately for each subdimension of the SF-36 QoLS and range between 0 and 100. Increasing the scores obtained from the scales indicates an increase in the quality of life. $\operatorname{Pinar}^{27}$ has conducted the Turkish adaptation of the scale, and the Cronbach's alpha value was found to be 0.92 . The SF-36 QoLS Cronbach's alpha value was found to be 0.84 in our study.

\section{Procedure}

After the necessary permissions for the study to be conducted were obtained, the data forms were completed by investigators and/or a properly trained nurse interviewer by using the face-to-face interview method by meeting the women during weekdays between 12 February and 6 April 2018 at the internal medicine outpatient departments of the training and research hospital where the study was conducted. The FPG, HDL-C, and TG values of the women were recorded from the routine laboratory results. The investigators and/or a trained nurse interviewer measured the women's blood pressure, waist circumference, height, and weight were measured by the investigators and/or a trained nurse interviewer.

Whether metabolic syndrome was present was determined in all the women included in the study with the IDF metabolic syndrome diagnostic criteria by using the TG, HDL-C, FPG, waist circumference, and blood pressure values. 


\section{Statistical analysis}

The data were evaluated using the SPSS Statistics 24.0 software program (IBM Corp., Armonk, NY). The Shapiro-Wilk test was used to determine whether the data were distributed normally. The number, percentage, mean, standard deviation, median, $25 \%$, and $75 \%$ percentile values were used as descriptive statistics. The Mann-Whitney $U$ test was used to compare MetS with the median scores obtained from the quality of life and sleep. Cronbach's alpha values were also assessed to determine the validity and reliability of the scales. The significance level was accepted as $p<0.05$ in the study.

\section{RESULTS}

The mean age of the women included in the study was $38.41 \pm 12.54$ years; $42.5 \%$ were primary school graduates and $28.2 \%$ university graduates, while $75.8 \%$ were married and $72.3 \%$ had children. Of the women, $73.7 \%$ were found not to have an incomegenerating job, $49.5 \%$ stated that they had an income less than their expenses, and $87.4 \%$ had social security. When healthy lifestyle behaviors were evaluated, $12.6 \%$ of the women stated that they were currently smoking, $77.2 \%$ were not involved in regular physical activity, and $42.2 \%$ stated that they did not eat healthy food. The mean BMI was $28.49 \pm 6.29 ; 37.2 \%$ were obese, and $34.7 \%$ had normal weight. When their personal histories were evaluated, $74.2 \%$ of the women stated they had not entered menopause, $45.2 \%$ had a chronic disease, $18.3 \%$ had diabetes mellitus (DM), and 15.3\% had been diagnosed with hypertension (HT). DM was present in $41.4 \%$, HT in $53.5 \%$, and cardiovascular system disease in $36.3 \%$ of the family members of the women (Table 1).

MetS was present in $41.9 \%$ of the women included in the study according to IDF diagnostic criteria. When MetS components were evaluated, the mean waist circumference was $104.03 \pm 15.36 \mathrm{~cm}$, the mean systolic and diastolic blood pressure was 119.83 $\pm 15.08 \mathrm{mmHg}$ and $76.20 \pm 10.33 \mathrm{mmHg}$, respectively, and the mean FPG, TG, and HDL-C levels were $104.68 \pm 39.07 \mathrm{mg} / \mathrm{dL}, 136.41 \pm 83.99$ $\mathrm{mg} / \mathrm{dL}$, and $50.90 \pm 12.71 \mathrm{mg} / \mathrm{dL}$ respectively (Table $1)$.

Table 1. The descriptive characteristics and metabolic syndrome status of the women

\begin{tabular}{|l|c|c|}
\hline Characteristics & \multicolumn{1}{|c|}{$\begin{array}{c}\text { Number } \\
(\mathrm{n}=372)\end{array}$} \\
\hline Age (Mean \pm SD) & \multicolumn{2}{|c|}{$38.41 \pm 12.54$} \\
\hline Educational status & \multicolumn{2}{|c|}{} \\
\hline Not literate & 158 & 5.6 \\
\hline Primary school & 30 & 42.5 \\
\hline Secondary school & 58 & 15.6 \\
\hline High school & 105 & 28.2 \\
\hline University & & \\
\hline Marital status & 282 & 75.8 \\
\hline Married & 90 & 24.2 \\
\hline Single & & 26.3 \\
\hline Occupational status & 98 & 73.7 \\
\hline Works & 274 & 87.4 \\
\hline Does not work & & 12.6 \\
\hline Social security & 325 & \\
\hline Present & 47 & 49.5 \\
\hline Absent & & 44.6 \\
\hline Income status & 184 & 5.9 \\
\hline Income less than expenses & 166 & 80.9 \\
\hline Income equal to expenses & 22 & 6.5 \\
\hline Income more than expenses & & 12.6 \\
\hline Smoking status & 301 & \\
\hline Never smoked & 24 & \\
\hline Smoked and quit & 47 & \\
\hline Current smoker & & \\
\hline Regular physical activity & & \\
\hline
\end{tabular}




\begin{tabular}{|c|c|c|}
\hline Yes & 85 & 22.8 \\
\hline No & 287 & 77.2 \\
\hline \multicolumn{3}{|l|}{ Healthy diet based on self-expression } \\
\hline Yes & 215 & 57.8 \\
\hline No & 157 & 42.2 \\
\hline \multicolumn{3}{|l|}{ Menopausal } \\
\hline Yes & 96 & 25.8 \\
\hline No & 276 & 74.2 \\
\hline \multicolumn{3}{|l|}{ Chronic disease } \\
\hline Present & 168 & 45.2 \\
\hline Absent & 204 & 54.8 \\
\hline \multicolumn{3}{|l|}{ Diabetes mellitus } \\
\hline Present & 68 & 18.3 \\
\hline Absent & 304 & 81.7 \\
\hline \multicolumn{3}{|l|}{ Hypertension } \\
\hline Present & 57 & 15.3 \\
\hline Absent & 315 & 84.7 \\
\hline \multicolumn{3}{|l|}{ Diabetes mellitus in family members } \\
\hline Present & 154 & 41.4 \\
\hline Absent & 218 & 58.6 \\
\hline \multicolumn{3}{|l|}{ Hypertension in family members } \\
\hline Present & 199 & 53.5 \\
\hline Absent & 173 & 46.5 \\
\hline \multicolumn{3}{|l|}{ Cardiovascular system disease in family members } \\
\hline Present & 135 & 36.3 \\
\hline Absent & 237 & 63.7 \\
\hline \multicolumn{3}{|l|}{ Body mass index(BMI) } \\
\hline Low weight & 6 & 1.6 \\
\hline Normal & 129 & 34.7 \\
\hline Overweight & 99 & 26.5 \\
\hline Obese & 138 & 37.2 \\
\hline BMI $\left(\right.$ Mean \pm SD) $\left(\mathrm{kg} / \mathrm{m}^{2}\right)$ & \multicolumn{2}{|c|}{$28.49 \pm 6.29$} \\
\hline \multicolumn{3}{|l|}{ Metabolic syndrome } \\
\hline Present & 156 & 41.9 \\
\hline Absent & 216 & 58.1 \\
\hline \multicolumn{3}{|l|}{ Metabolic syndrome components (Mean \pm SD) } \\
\hline Waist circumference $(\mathrm{cm})$ & \multicolumn{2}{|c|}{$104.03 \pm 15.36$} \\
\hline Systolic blood pressures $(\mathrm{mmHg})$ & \multicolumn{2}{|c|}{$119.83 \pm 15.08$} \\
\hline Diastolic blood pressure $(\mathrm{mmHg})$ & \multicolumn{2}{|c|}{$76.20 \pm 10.33$} \\
\hline Triglycerides $(\mathrm{mg} / \mathrm{dL})$ & \multicolumn{2}{|c|}{$136.41 \pm 83.99$} \\
\hline High-density lipoprotein cholesterol $(\mathrm{mg} / \mathrm{dL})$ & \multicolumn{2}{|c|}{$50.90 \pm 12.71$} \\
\hline Fasting plasma glucose $(\mathrm{mg} / \mathrm{dL})$ & \multicolumn{2}{|c|}{$104.68 \pm 39.07$} \\
\hline
\end{tabular}

The mean sleep duration in the previous night was $6.71 \pm 1.37$ hours. The mean sleep duration was $6.55 \pm 1.46$ hours in the women with MetS and $6.83 \pm 1.29$ hours in the women without MetS $(p<0.05)$. The mean PSQI daytime dysfunction subdimension score was lower in women with MetS than those without MetS $(p<0.05)$. The scores of the PSQI sub-dimensions other than daytime dysfunction and global PSQI mean scores of the women with MetS were higher than those without MetS $(p<0.05)$. No statistically significant difference was found between the PSQI sleep latency sub-dimension median score and the presence of MetS $(p>0.05)$ (Table 2). 
Table 2. Comparison of Pittsburgh Sleep Quality Index scores of women without metabolic syndrome and with metabolic syndrome

\begin{tabular}{|l|c|c|c|c|c|}
\hline \multirow{2}{*}{$\begin{array}{l}\text { Pittsburgh Sleep } \\
\text { Quality Index }\end{array}$} & \multicolumn{2}{|c|}{ Metabolic Syndrome Present } & \multicolumn{2}{|c|}{ Metabolic Syndrome Absent } & \\
\cline { 2 - 5 } & Mean \pm SD & $\begin{array}{c}\text { Median } \\
*(25 \mathrm{p}-\% 75 \mathrm{p})\end{array}$ & Mean \pm SD & $\begin{array}{c}\text { Median } \\
*(\% 25 \mathrm{p}-\% 75 \mathrm{p})\end{array}$ & $\begin{array}{c}\boldsymbol{p}^{-} \\
\text {value** }\end{array}$ \\
\hline $\begin{array}{l}\text { Subjective sleep } \\
\text { quality }\end{array}$ & $1.47 \pm 0.75$ & $1.0(1.00-2.00)$ & $1.31 \pm 0.78$ & $1.00(1.00-2.00)$ & 0.043 \\
\hline Sleep latency & $1.66 \pm 1.09$ & $2.0(1.00-3.00)$ & $1.45 \pm 0.92$ & $1.00(1.00-2.00)$ & 0.055 \\
\hline Sleep duration & $0.81 \pm 0.96$ & $0.0(0.00-1.75)$ & $0.59 \pm 0.83$ & $0.00(0.00-1.00)$ & 0.028 \\
\hline $\begin{array}{l}\text { Habitual sleep } \\
\text { efficiency }\end{array}$ & $0.81 \pm 1.00$ & $0.0(0.00-1.00)$ & $0.60 \pm 0.94$ & $0.00(0.00-1.00)$ & 0.018 \\
\hline Sleep disturbances & $1.64 \pm 0.67$ & $2.0(1.00-2.00)$ & $1.45 \pm 0.65$ & $1.00(1.00-2.00)$ & 0.004 \\
\hline $\begin{array}{l}\text { Use of sleep } \\
\text { medications }\end{array}$ & $0.28 \pm 0.84$ & $0.0(0.00-0.00)$ & $0.11 \pm 0.50$ & $0.00(0.00-0.00)$ & 0.031 \\
\hline $\begin{array}{l}\text { Daytime } \\
\text { dysfunction }\end{array}$ & $0.73 \pm 0.78$ & $1.0(0.00-1.00)$ & $0.99 \pm 0.98$ & $1.00(0.00-2.00)$ & 0.024 \\
\hline Global PSQI score & $7.42 \pm 3.62$ & $7.0(5.00-10.00)$ & $6.52 \pm 3.50$ & $6.00(4.00-9.00)$ & 0.016 \\
\hline
\end{tabular}

The median scores of the MetS patients from the general health perception, physical function, role difficulty, bodily pain, and mental component summary sub-dimensions of the SF-36 QoLS were lower than those without MetS $(p<0.001)$. Although the SF-36 QoLS's vitality, emotional role limitations, and mental health sub-dimension median scores were lower in subjects with MetS than in those without MetS, this difference was not found to be statistically significant $(p>0.05)$ (Table 3).

Table 3. Comparison of SF-36 Quality of Life Scale sub-dimensions scores of women without metabolic syndrome and with metabolic syndrome

\begin{tabular}{|c|c|c|c|c|c|}
\hline \multirow{2}{*}{$\begin{array}{l}\text { SF-36 Quality of Life } \\
\text { Scale } \\
\text { sub-dimensions }\end{array}$} & \multicolumn{2}{|c|}{ Metabolic syndrome present } & \multicolumn{2}{|c|}{ Metabolic syndrome absent } & \multirow{2}{*}{$\begin{array}{c}\mathrm{p}- \\
\text { value** }\end{array}$} \\
\hline & Mean \pm SD & $\begin{array}{c}\text { Median } \\
*(\% 25 \mathrm{p}-\% 75 \mathrm{p})\end{array}$ & Mean \pm SD & $\begin{array}{c}\text { Median } \\
*(\% 25 \mathrm{p}-\% 75 \mathrm{p})\end{array}$ & \\
\hline Physical functioning & $66.12 \pm 26.22$ & $\begin{array}{c}65.00 \\
(46.25-90.00)\end{array}$ & $75.74 \pm 23.95$ & $\begin{array}{c}85.00 \\
(60.00-95.00)\end{array}$ & $<0.001$ \\
\hline $\begin{array}{l}\text { Role limitation- } \\
\text { Physical }\end{array}$ & $44.87 \pm 42.18$ & $\begin{array}{c}25.00 \\
(0.00-100)\end{array}$ & $57.98 \pm 43.16$ & $\begin{array}{c}75.00 \\
(0.00-100)\end{array}$ & 0.005 \\
\hline Bodily pain & $44.93 \pm 25.84$ & $\begin{array}{c}40.00 \\
(30.00-60.00)\end{array}$ & $55.27 \pm 23.18$ & $\begin{array}{c}50.00 \\
(40.00-70.00)\end{array}$ & $<0.001$ \\
\hline $\begin{array}{l}\text { General health } \\
\text { perception }\end{array}$ & $47.94 \pm 22.85$ & $\begin{array}{c}50.00 \\
(30.00-65.00)\end{array}$ & $54.46 \pm 21.82$ & $\begin{array}{c}55.00 \\
(40.00-70.00)\end{array}$ & 0.009 \\
\hline Vitality (Energy) & $47.17 \pm 24.35$ & $\begin{array}{c}50.00 \\
(30.00-65.00)\end{array}$ & $51.15 \pm 23.21$ & $\begin{array}{c}50.00 \\
(35.00-70.00)\end{array}$ & 0.138 \\
\hline Social functioning & $71.55 \pm 26.99$ & $\begin{array}{c}75.00 \\
(50.00-100)\end{array}$ & $71.87 \pm 24.94$ & $\begin{array}{c}75.00 \\
(50.00-100)\end{array}$ & 0.853 \\
\hline $\begin{array}{l}\text { Role limitation- } \\
\text { Emotional }\end{array}$ & $61.32 \pm 44.56$ & $\begin{array}{c}100 \\
(0.00-100)\end{array}$ & $64.66 \pm 41.05$ & $\begin{array}{c}100 \\
(33.33-100)\end{array}$ & 0.663 \\
\hline Mental health & $54.28 \pm 19.80$ & $\begin{array}{c}54.00 \\
(44.00-68.00)\end{array}$ & $57.00 \pm 20.29$ & $\begin{array}{c}60.00 \\
(44.00-72.00)\end{array}$ & 0.145 \\
\hline $\begin{array}{l}\text { Physical component } \\
\text { summary }\end{array}$ & $43.44 \pm 11.30$ & $\begin{array}{c}45.13 \\
(36.08-51.71)\end{array}$ & $43.17 \pm 11.08$ & $\begin{array}{c}44.24 \\
(36.30-51.94)\end{array}$ & 0.921 \\
\hline $\begin{array}{l}\text { Mental component } \\
\text { summary }\end{array}$ & $39.22 \pm 10.43$ & $\begin{array}{c}39.08 \\
(31.10-47.22)\end{array}$ & $44.09 \pm 9.27$ & $\begin{array}{c}45.84 \\
(37.78-50.99)\end{array}$ & $<0.001$ \\
\hline
\end{tabular}




\section{DISCUSSION}

The incidence of MetS is gradually increasing worldwide, which in turn increases both the risk of developing diabetes and the relevant expenses. Identifying MetS and ensuring effective management are important in decreasing other health risks in the population and healthcare expenses ${ }^{5,28}$. The MetS prevalence in women was found to be $41.9 \%$ in our study. Other studies conducted in our country have reported the MetS prevalence in women according to IDF diagnostic criteria to vary between $38.5 \%$ and $49.8 \% 0^{7,22,29,30}$

The MetS prevalence in women as based on IDF criteria has been reported to be $17.4 \%$ in the Philippines, $20.0 \%$ in China, $33.0 \%$ in Australia, and $47.2 \%$ in India in a systematic review of adults in the Asian-Pacific region ${ }^{31}$. MetS prevalence in women was $42.0 \%$ in a systematic review and meta-analysis study using the same criteria conducted in $\operatorname{Iran}^{32}$. The MetS prevalence in women in our study was similar to the studies conducted by Soysal et al. (38.5\%)22 and Oğuz et al. (44.8\%) 7 in our country by Amirkalali et al. ${ }^{32}$ in Iran. The high MetS prevalence in our study is thought to be due to the use of subjects who had presented to internal medicine outpatient departments.

The quantity and quality of sleep play an important role in maintaining daily metabolic and hormonal processes 9,33 . Short or long sleep duration is reported to increase the risk of MetS development in the literature ${ }^{15,16}$. The sleep duration in the previous night of women with MetS in our study was found to be shorter than those without MetS $(p<0.05)$. Short sleep duration was reported to be related to MetS in another study, similar to our study finding ${ }^{34}$. PSQI sub-dimensions except for daytime dysfunction and sleep latency and global PSQI mean scores were higher in the women found to have MetS in our study $(p<0.05)$. The mean scores of PSQI sub-dimensions other than daytime dysfunction, sleep duration, subjective sleep quality, and global PSQI score were higher in women with MetS in the study of Okubo et al. $(p<0.05)^{10}$. The PSQI sleep duration, sleep disturbances, use of sleep medications sub-dimension scores, and mean global PSQI scores were found to be higher in individuals with MetS in the study of Zohal et al. $(p<0.05)^{14}$. Hung et al. ${ }^{9}$ found the mean global PSQI score in individuals with MetS to be higher than those without MetS $(p<0.001)$. The findings of the study mentioned above $\mathrm{e}^{9,10,14}$ support those from our study. However, there are also studies reporting no significant relationship between sleep quality and MetS in the literature ${ }^{35,36}$. These contrasting results are thought to be due to various criteria for identifying MetS and the differences in the characteristics of the study populations.

MetS is reported to decrease the quality of life $\mathrm{e}^{17,18}$. SF-36 QoLS general health perception, physical function, role limitation, bodily pain, and mental component summary sub-dimensions median scores of the women with MetS were lower than those without MetS $(p<0.05)$. A study on Pakistani immigrant women has found the SF-36 QoLS general health, physical function, and bodily pain subdimensions to be higher in women with $\mathrm{MetS}^{37}$. MetS was found to harm the SF-36 QoLS physical health components (physical function, bodily pain, physical role difficulty, general health) in women in a study where gender-related factors were evaluated ${ }^{38}$. The mean scores obtained by individuals with MetS from all sub-dimensions of the SF-36 QoLS except the bodily pain sub-dimension were significantly lower in the study of Tziallas et al. ${ }^{21}$ covering a mixed-gender population. The quality of life in subjects with MetS is lower in other studies as well ${ }^{17,20}$. Similar to the studies mentioned above, we found the quality of life of women to be negatively affected by MetS. Interventions by health care professionals that will ensure that patients with MetS lead a healthy lifestyle are needed to increase the quality of life.

This study had some limitations. One of these was the fact that it was not a community-based study. Another limitation was that the findings obtained from the women presenting to the internal medicine outpatients of a single training and research hospital could only be generalized to the study universe.

In conclusion, the MetS prevalence in women was found to be high in our study. MetS was also found to affect the quality of life and sleep negatively in women. MetS itself and the associated sleep disorders may lead to many diseases and increase mortality, morbidity, and treatment costs $9,10,28$. The prevention of these problems requires preventing the development of MetS in women. Health care professionals need to direct the women toward a healthy lifestyle starting from childhood to prevent MetS development. However, many women do not know they have MetS. Diagnosis and follow-up of MetS in women by health care professionals are therefore required at regular intervals. It is also necessary to raise the awareness of the individuals in 
the society about this issue. Training and counseling services should also be provided to improve the quality of life and sleep in women who have MetS and prevent or control any health problems.

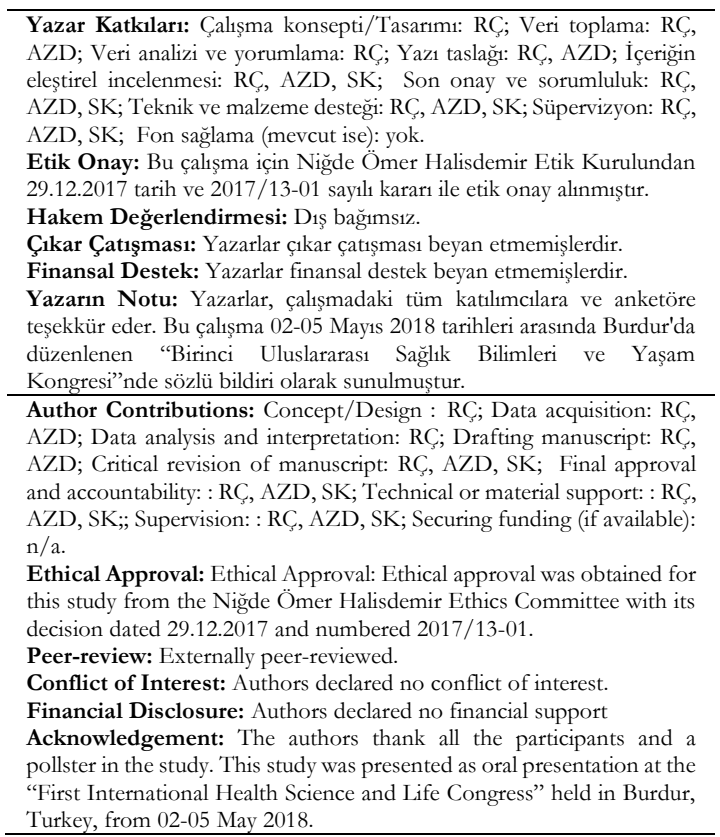

\section{REFERENCES}

1. Grundy SM. Metabolic syndrome update. Trends Cardiovasc Med. 2016;26:364-73.

2. Kozan O, Oguz A, Abaci A, Erol C, Ongen Z, Temizhan A, et al. Prevalence of the metabolic syndrome among Turkish adults. Eur J Clin Nutr. 2007;61:548-53

3. Rochlani Y, Pothineni NV, Kovelamudi S, Mehta JL. Metabolic syndrome: pathophysiology, management, and modulation by natural compounds. Ther Adv Cardiovasc Dis. 2017;11:215-25.

4. Bhalwar R. Metabolic syndrome: The Indian public health

Med J Armed Forces India. 2020;76:8-16. perspective.

5. Kassi E, Pervanidou P, Kaltsas G, Chrousos G. Metabolic syndrome: definitions and controversies. BMC Med. 2011;9:48

6. Saklayen MG. The global epidemic of the metabolic syndrome. Curr Hypertens Rep. 2018;20:12

7. Oğuz A, Telci Çaklılı Ö, Tümerdem Çalık B, PURE Investigators. The Prospective Urban Rural Epidemiology (PURE) study: PURE Turkey. Turk Kardiyol Dern Ars. 2018;46:613-23.

8. Lian Y, Yuan Q, Wang G, Tang F. Association between sleep quality and metabolic syndrome: a systematic review and meta-analysis. Psychiatry Res. 2019;274:66-74.
9. Hung HC, Yang YC, Ou HY, Wu JS, Lu FH, Chang CJ. The association between self-reported sleep quality and metabolic syndrome. PLoS One. 2013;8:e54304.

10. Okubo N, Matsuzaka M, Takahashi I, Sawada K, Sato $\mathrm{S}$, Akimoto $\mathrm{N}$, et al. Relationship between selfreported sleep quality and metabolic syndrome in general population. BMC Public Health. 2014;14:562.

11. Aldabal L, Bahammam AS. Metabolic, endocrine and immune consequences of sleep deprivation. Open Respir Med J. 2011;5:31-43.

12. Landis CA. Physiological and behavioral aspects of sleep. In Sleep Disorders and Sleep Promotion in Nursing Practice (Eds Redeker NS, McEnany GP.):118, New York, Springer Publishing, 2011.

13. Nedeltcheva AV, Scheer FA. Metabolic effects of sleep disruption, links to obesity and diabetes. Curr Opin Endocrinol Diabetes Obes. 2014;21:293-98.

14. Zohal M, Ghorbani A, Esmailzadehha N, Ziaee A, Mohammadi Z. Association of sleep quality components and wake time with metabolic syndrome: The Qazvin Metabolic Diseases Study (QMDS), Iran. Diabetes Metab Syndr. 2017;11:377-80.

15. Fan L, Hao Z, Gao L, Qi M, Feng S, Zhou G. Nonlinear relationship between sleep duration and metabolic syndrome: A population-based study. Medicine (Baltimore). 2020;99:e18753.

16. Lu K, Zhao Y, Chen J, Hu D, Xiao H. Interactive association of sleep duration and sleep quality with the prevalence of metabolic syndrome in adult Chinese males. Exp Ther Med. 2020;19:841-48.

17. Saboya PP, Bodanese LC, Zimmermann PR, Gustavo AS, Assumpção CM, Londero F. Metabolic syndrome and quality of life: a systematic review. Rev Lat Am Enfermagem. 2016;24:e2848.

18. Postolova A, Dorani O, Brown K, Powell-Hicks A, Dous G, Becker B, et al. Health related quality of life in patients with metabolic syndrome. J Sci Res Rep. 2014;3:1088-104.

19. Chiang LC, Chiang SL, Tzeng WC, Lee MS, Hung YJ, Lin $\mathrm{CH}$. Active physical activity patterns are associated with improved quality of life and depression status in Taiwanese women with metabolic syndrome. J Cardiovasc Nurs. 2019;34:491-502.

20. Jahangiry L, Shojaeezadeh D, Montazeri A, Najafi M, Mohammad K. Health-related quality of life among people participating in a metabolic syndrome escreening program: a web-based study. Int J Prev Med. 2016;7:27.

21. Tziallas D, Kastanioti C, Kostapanos MS, Skapinakis $\mathrm{P}$, Elisaf MS, Mavreas V. The impact of the metabolic syndrome on health-related quality of life: a crosssectional study in Greece. Eur J Cardiovasc Nurs. 2012;11:297-303.

22. Soysal A, Şimşek H, Doğanay S, Günay T. Prevalence of metabolic syndrome and affecting factors among individuals aged 30 and over in Balçova district of İzmir. Balkan Med J. 2016;33:331-38. 
23. The IDF consensus worldwide definition of the metabolic syndrome. (2006). International Diabetes Federation. https://www.idf.org/elibrary/consensus-statements/60-idfconsensusworldwide-definitionof-the-metabolic-syndrome (accessed March 2020)

24. Buysse DJ, Reynolds CF, Monk TH, Berman SR, Kupfer DJ. The Pittsburgh sleep quality index: a new instrument for psychiatric practice and research. Psychiatry Res.1989;28:193-213.

25. Ağargün MY, Kara H, Anlar O. Pittsburgh Uyku Kalitesi İndeksi'nin geçerliği ve güvenirliği. Turk Psikiyatri Derg.1996;7:107-15.

26. Ware JE, Sherbourne CD. The MOS 36-item shortform health survey (SF-36). I. Conceptual framework and item selection. Med Care. 1992;30:473-83.

27. Pınar R. Sağlık araștırmalarında yeni bir kavram: Yaşam kalitesi - Bir yaşam kalitesi ölçeğinin kronik hastalarda geçerlik ve güvenirliğinin incelenmesi. Hemşirelik Bülteni. 1995;9:85-95.

28. Marangos PJ, Okamoto LJ, Caro JJ. Economic burden of the components of the metabolic syndrome. In: Handbook of disease burdens and quality of life measures (Eds Preedy VR, Watson RR.):1135-149. New York, Springer Publishing, 2010.

29. Gemalmaz A, Aydın S, Başak O, Disçigil G, Karul A. Prevalence of the metabolic syndrome in a rural Turkish population: Comparison and concordance of two diagnostic criteria. Turk J Med Sci. 2008;38:15965.

30. Gundogan K, Bayram F, Gedik V, Kaya A, Karaman A, Demir O, et al. Metabolic syndrome prevalence according to ATP III and IDF criteria and related factors in Turkish adults. Arch Med Sci. 2013;9:24353.

31. Ranasinghe $\mathrm{P}$, Mathangasinghe $\mathrm{Y}$, Jayawardena R, Hills AP, Misra A. Prevalence and trends of metabolic syndrome among adults in the Asia-Pacific region: a systematic review. BMC Public Health. 2017;17:101.

32. Amirkalali B, Fakhrzadeh H, Sharifi F, Kelishadi R, Zamani F, Asayesh H, et al. Prevalence of metabolic syndrome and its components in the Iranian adult population: A systematic review and meta-analysis. Iran Red Crescent Med J. 2015;17:e24723.

33. Lin SC, Sun CA, You SL, Hwang LC, Liang CY, Yang $\mathrm{T}$, et al. The link of self-reported insomnia symptoms and sleep duration with metabolic syndrome: a Chinese population-based study. Sleep. 2016;39:1261-66.

34. Kobayashi D, Takahashi O, Deshpande GA, Shimbo T, Fukui T. Relation between metabolic syndrome and sleep duration in Japan: a large scale cross-sectional study. Intern Med. 2011;50:103-07.

35. Chang JH, Huang PT, Lin YK, Lin CE, Lin CM, Shieh $\mathrm{YH}$, et al. Association between sleep duration and sleep quality, and metabolic syndrome in Taiwanese police officers. Int J Occup Med Environ Health. 2015;28:1011-23.

36. Kazman JB, Abraham PA, Zeno SA, Poth M, Deuster PA. Self-reported sleep impairment and the metabolic syndrome among African Americans. Ethn Dis. 2012;22:410-15.

37. Hjellset VT, Ihlebæk CM, Bjørge B, Eriksen HR, Høstmark AT. Health-related quality of life, subjective health complaints, psychological distress and coping in Pakistani immigrant women with and without the metabolic syndrome: The InnvaDiabDEPLAN study on Pakistani immigrant women living in Oslo, Norway. J Immigr Minor Health. 2011;13:732-41.

38. Amiri P, Deihim $\mathrm{T}$, Taherian $\mathrm{R}$, Karimi $\mathrm{M}$, Gharibzadeh S, Asghari-Jafarabadi M, et al. Factors affecting gender differences in the association between health-related quality of life and metabolic syndrome components: Tehran lipid and glucose study. PLoS One. 2015;10:e0143167. 